\title{
Assessment of Polycyclic Aromatic Hydrocarbons in Heat Treated Meat and Fish
}

\author{
Abelrahman, H.A ${ }^{\mathbf{1}}$; Salwa M. Salem ${ }^{2}$ and Enas A.Eltantawy ${ }^{\mathbf{3}}$ \\ ${ }^{1}$ Faculty of Veterinary Medicine, Suez Canal University ${ }^{2}$ Animal \\ Health Institute Ismailia ${ }^{3}$ Directorate of Veterinary Medicine in \\ Sharkia
}

\begin{abstract}
:
This study was conducted to assess the concentrations of the polycyclic aromatic hydrocarbons (16PAH, PAH4 and PAH8) in the examined samples of six heat treated Egyptian charcoal grilled meat ball (kofta), gas chicken Shawerma, charcoal and gas grilled Chicken, charcoal grilled Fish and cold smoked Herring which are widely consumed as family meal, take-away or as sandwiches in Egypt. The samples were collected from different restaurants, Hyper-Markets and grilled Shops in Ismailia Governorate. Four samples from each of the six heat treated product were analyzed by using HPLC analysis using a Shimadzu LC20 series (Kyoto, Japan) with a fluorescence detector (RF-10AxL) and a ZORBAX Eclipse PAH $(2.1 \times 150$ $\mathrm{mm}, 3.5 \mathrm{~lm}$, Agilent) as a separation column. The PAHs concentration levels in examined samples varied mainly according to heat treated method. Charcoal and gas grilling cooking process were release high concentrations of total PAH4 and PAH8 in heat treated meat products and fish.
\end{abstract}

Key words: PAHs, grilled meat, smoked Fish. PAHs hazards

\section{Introduction:}

Cooking is a process for making food palatable for ingestion, it is a chemical process where the raw food materials are exposed to heat source to become ready for consumption. The aim of cooking is to improving the taste, quality and digestibility of cooked food, destruction of microorganisms, increases variety, and increases consumption of food. Grilling is a type of cooking, the grilled meat are the favorite in home and restaurants, these barbecued meats may pose risk to the consumers health due to increasing of pro-carcinogen compounds which may be found in such meat in a comparison to meats prepared by other alternative cooking methods. Grilled meat and meat products acquired a distinctive grilled aroma and flavor due to 
the Maillard reaction this occurs only when foods reach temperatures of $155^{\circ} \mathrm{C}$ or more (Schröder et al., 2003).The PAHs are group of chemicals compound that formed during the in complete burning of the organic materials. Hundreds of PAHs are generally occurring as a complex mixture that have relatively low levels of solubility in water but are highly lipophilic in nature and they are found in the air, water and soil. They are ubiquitous pollutants, originated from environmental sources as natural and anthropogenic, industrial food processing sources as heating, drying, grilling, roasting, frying and even smoking processes, in addition to the packaging materials can be generated (Jägerstad\& Skog, 2005) and (EFSA, 2008). Food is the main source of contamination by PAHs for non-smokers or nonoccupationally subjected adults. It was recorded that the diet only contributes more than $90 \%$ of the total PAHs exposure of the population in different countries (Liobet et al., 2006). The average dietary intake of ei ght carcinogenic and genotoxic PAH

8 [Chrysene, Benzo (a) pyrene, Benzo (b) fluoranthene, Benzo ( $\mathrm{k})$

Fluoranthene, Dibenzo (a, h) ant hracene, Benzo (g, h, I perylene, Benzo (a) anthracene and Inden o $(1,2,3 \mathrm{c}, \mathrm{d})$ pyrene] was measu red at $1.73 \mathrm{mg} /$ day (EFSA, 2008). The PAHs is not usually observed in raw foods, but can be observed

specially in grilled foods and it have been reported to contain PAHs at levels up to $130 \mathrm{mg} / \mathrm{kg}$ (WHO, 1989 and Farhadian et al., 2010). The variation levels of PAHs in foods is mainly due to the fat content, cooking process, duration of the cooking, type of fuel used and degree of the heat source which combining the direct contact with food. IARC, (1987) states that the $\mathrm{BaP}$ as probable carcinogen for human therefore, the estimation of $\mathrm{BaP}$ has been internationally used as a marker for the PAH content. The permitted maximum concentrations of $\mathrm{BaP}$ in foodstuffs have been established by the EU at $5 \mathrm{ppb}(\boldsymbol{E S}, 2005$ and IARC, 2010) which classified the PAHs according to their carcinogenicity into Group 1 which is highly carcinogen as $\mathrm{B}$ [a] P;

Group 2A which is probable carcinogen as dibenzo $[a, h]$ anthracene; the third group is possible carcinogen and put under Group 2B as benz[a]anthracene, benzo[b]fluoranthene anvchrysene.

An epidemiological study has $\mathrm{s}$ hown that the high consumptio $\mathrm{n}$ of heat treated meat contributes to 
increased

colon

and rectal cancer risk (Sinha et al., 2005 \& Mafiana et al., 2018)

reported that the diet contributes more than $80 \%$ of the known colorectal cancer cases they found that a positive correlation between the incidence of colorectal cancers and the higher meat intakes. Buamden (2018) mentioned that the highest incidences of colorectal cancer cases in Uruguay, Barbados, Argentina and Cuba and were strongly associated with the consumption of animal red meat and fat. (Alomirah et al., 2011) stimated the levels and dietary intake

of 16 PAHs in various grilled fo ods in Kuwaiti populations and $r$ ecorded non-carcinogenic PAHs were present at high proportions (60-100\%). Meat dishes prepared by charcoal or gas grilling, and smoking that are increasingly popular and preferred at home, barbecue and in restaurants in Egypt. (Darwish et al., (2019) studied the formation of PAHs in some heat-treated meat products in Egypt and reported that the heavy dietary intake of PAHs of meat may increase the cancer risk among the Egyptian population. Heat treated meat have a concentration of $\mathrm{B}[\mathrm{a}] \mathrm{P}$ lead to mutagenesis due to production of higher levels of ROS in CaCo-2 cells.

\section{Materials and Methods: Samples collection}

A total of 24 samples four each of charcoal grilled Meat Ball (Kofta), chicken Shawerma, charcoal grilled Chicken, gas grilled Chicken, gas grilled Fish and smoked Herring were collected from different localities from Restaurants, grilled Shops and Hyper Markets in Ismailia Governorate, Egypt. The samples were stored at $-20^{\circ} \mathrm{C}$ until time of extraction and measurement of PAHs. PAHs extraction, analysis and quality

assurance:

Extraction, analysis and quality assurance of PAHs: PAHs were analyzed according the method defined by (Ikenaka et al., 2008 \& Dar wish et al., 2019) and by using HPLC analysis using a Shimadzu LC20 series (Kyoto, Japan) with a fluorescence detector (RF-10AxL) and a ZORBAX Eclipse PAH $(2.1 \times 150 \mathrm{~mm}, 3.5 \mathrm{~lm}$, Agilent) as a separation column.

\section{Results \&Discussion:}

Heat treatment of meat products and fish was primarily aiming to removal of microbial contaminants; in addition, cooking makes cooked food digestible, palatable and have specific flavour and aroma. However, the heat treatment at elevated temperatures leads to the formation of several toxic 
and harmful PAHs. The present study was conducted to estimate the levels of PAHs in retailed charcoal, gas, grilled and smoking meat products and fish. In the current study, the estimated international known PAHs were grouped as PAH4, PAH8 and 16 PAHs. The achieved results as given in Table (1) and Fig.(1) revealed that, the mean values \pm SD of PAH4 \& PAH8 in the examined samples were on the following significant $(\mathrm{P}<0.05)$ descending order; charcoal grilled kofta, gas chicken Shawerma, gas grilled Chicken, charcoal grilled Chicken, charcoal grilled Fish and cold smoked Herring were $3.43 \pm 0.77 ; 3.28 \pm 0.27 ; 3.45 \pm$ $0.53 ; 0.09 \pm 0.02 ; 1.43 \pm 0.26$ and $0.09 \pm 0.03$ respectively , while the mean values of the estimated PAH8 in the examined samples were $8.12 \pm 1.89 ; 10.06$ $\pm 2.49 ; 9.44 \pm 2.89 ; 0.65 \pm 0.16$ ; $4.22 \pm 1.43$ and $0.18 \pm 0.03$ respectively . The estimated minimum and maximum \pm SD values of the priority PAH16 in the examined samples of heat treated meat and fish as given in Table (1) and Fig.(1) were ; in gas grilled Kofta was $0.01 \pm$ $0.00 ; 2.23 \pm 0.7$ for fluorene and benzo[g,h,i]perylene ; in gas grilled shawerma was $0.20 \pm$ $0.11 ; 3.31 \pm 1.87$ for naphthalene and benzo[k]fluoranthene; in charcoal grilled chicken was $0.07 \pm 0.08 ; 2.29 \pm 1.68$ for anthracene and naphthalene ; in gas grilled chicken was $0.01 \pm$ $0.01 ; 0.50 \pm 0.14$ for acenaphthylene and benzo[k]fluoranthene; in gas grilled fish was $0.01 b \pm 0.01$; $2.49 \pm 0.97$ for fluorene and acenaphthylene and in smoked Herring was $0.01 \pm 0.01$ and 0.03 \pm 0.01 for fluorene and anthracene respectively. Unlikely, lower result were recorded than that obtained by Eldaly et al. (2016) they did not detect benzo[ghi]perylene in the examined non-marinated charcoal grilled Kofta samples but Benzo(a)anthracene and Benzo(a)pyrene were only found with maximum concentrations of $33.2 \pm 4$ and $26 \pm 16 \mu \mathrm{g} / \mathrm{kg}$, respectively. As well as, the mean values of PAH4 and PAH8 \pm SD in Kofta were $3.43 \pm 0.77$ and $8.12 \pm 1.89 \mu \mathrm{g} / \mathrm{kg}$, respectively. The results obtained were lower than PAH4 and PAH8 in charcoal-beef grilled samples which recorded by Darwish et al. (2019). The detected $\mathrm{B}[\mathrm{a}] \mathrm{P}$, total $\mathrm{PAH} 4$ and PAH8 in this study were in agreement with MLs (5 ng/g ww) for PAHs in grilled meat and meat products which set by (EC, 2006 \& EFSA, 2008). However, the total PAH8 content for grilled chicken, kofta and shawerma was exceeded that recommend limits. $\boldsymbol{E F S \boldsymbol { A }}$ (2008) reported that $\mathrm{BaP}$ is not $\mathrm{c}$ 
onsidered to be an adequate pre dictr

of the occurrence of $\mathrm{PAH}$ in fo od and suggested the number of (BaA), (Chr), (BbF) and $\mathrm{BaP}$ as $\mathrm{PAH} 4$, as well as the sum of (BaA), (Chr), (BbF), (BaP), (BkF), (BghiP), (DahA), and (IcdP) as PAH8, is the most suitable criterion (Alomirah et al., 2011; Li, et al., 2016 ;Rozentale et al., 2015). Therefore, the $\boldsymbol{E C}$ (2011) stated that the MLs for BaP and PAH4 in smoked meat products were 2 and $12 \mu \mathrm{g} / \mathrm{kg}$., respectively. The obtained results were lower in all samples for both BaP and PAH4. The concentrations of $\mathrm{B}[\mathrm{a}] \mathrm{P}$ and 11 other PAHs in 322 commerc ial, meat products and 14 home grilled Estonian meat samples w ere analyzed and the highest concentrations o $\mathrm{f}$ PAH were detected in home grilled pork samples (Reinik $\boldsymbol{e t}$ al., 2007). Similarly, $\mathrm{B}[\mathrm{a}] \mathrm{P}$ concentrations were elevated in charcoal-barbecued chicken meat compared with that of roasted and raw chicken, with a concentration range of 0.09-6.94 ng/g ww in Korean charcoal cooked meat (Chung et al., 2011). However, the recorded concentrations of $\mathrm{B}[\mathrm{a}] \mathrm{P}$ in the present study were much lower than that recorded in Turkey, where $\mathrm{B}[\mathrm{a}] \mathrm{P}$ concentrations $(\mu \mathrm{g}$ $/ \mathrm{kg} \mathrm{ww)} \mathrm{were} 43.80 \pm 1.80$, $31.33 \pm 0.94$ and $62.60 \pm 3.72$,
$37.60 \pm 3.84$,respectively in grilled and grilled lamb and beef meats (Aygün, \& Kabadayi, 2005) additionally, (Olatunji et al., 2014) recorded higher concentrations $\quad(0.07-46.67$ $\mathrm{ng} / \mathrm{g}$ ) for benzo[k]fluoranthene, $\mathrm{B}$ [a]P, indeno [123-cd] pyrene and benzo[ghi]perylene in heatprocessed meat in South Africa ,while Phillips (1999) record higher level of PAHs in smoked fish and meat. The differences in the concentration levels of the formed 16 PAHs, PAH4 and PAH8 in the examined heattreated meat and fish may attributed to the cooking time, cooking temperature, distance between meat and the fire source, type of meat cut, fat content and type of meat additives.

Conclusion: The results revealed that the charcoal grilled chicken, Shawerma, kofta and gas grilled fish contained variable concentration levels of BaP, PAH4 and PAH8 which varies according to the methods of cooking and constitute a public health hazards, therefore, controlling of the cooking time, cooking temperature, distance between meat and the fire source, type of meat cut, and type of meat additives through further studies which are needed to reduce the formation of PAHs in the heat-treated meat products and fish. 
Table (1): Residual concentrations of PAHs $\mu \mathrm{g} / \mathrm{kg}$ in the examined Meat product \& fish samples exposed to different heat treatments $(n=24)$

\begin{tabular}{|c|c|c|c|c|c|c|c|}
\hline \multirow{3}{*}{ Item } & \multicolumn{7}{|c|}{ Heat treated Meat and Fish } \\
\hline & $\begin{array}{l}\text { C.G. } \\
\text { Kofta }\end{array}$ & G.G.Shawe. & C.G. Chi & G. G. Chi & G.G.fish & S. Herring & \multirow{2}{*}{$\begin{array}{c}P \\
\text { value }\end{array}$} \\
\hline & $\begin{array}{l}\text { Mean } \pm \\
\text { SD }\end{array}$ & Mean \pm SD & $\begin{array}{l}\text { Mean } \pm \\
\text { SD }\end{array}$ & $\begin{array}{c}\text { Mean } \pm \\
\text { SD }\end{array}$ & $\begin{array}{c}\text { Mean } \pm \\
\text { SD }\end{array}$ & Mean \pm SD & \\
\hline Nap & UDL & $0.20^{\mathrm{b}} \pm 0.11$ & $\begin{array}{c}2.29^{\mathrm{a}} \pm \\
1.68\end{array}$ & UDL & UDL & $\begin{array}{c}0.02^{\mathrm{b}} \pm \\
0.01\end{array}$ & $0.001^{* *}$ \\
\hline Ace & UDL & $1.48^{\mathrm{a}} \pm 1.45$ & UDL & UDL & UDL & $\begin{array}{c}0.02^{\mathrm{b}} \pm \\
0.01\end{array}$ & $0.016^{*}$ \\
\hline Flu & $\begin{array}{c}0.01^{\mathrm{b}} \pm \\
0.00\end{array}$ & UDL & UDL & UDL & UDL & $\begin{array}{c}0.01^{b} \pm \\
0.01\end{array}$ & $0.001^{* *}$ \\
\hline Ant & UDL & UDL & UDL & UDL & UDL & $\begin{array}{c}0.03^{\mathrm{b}} \pm \\
0.01\end{array}$ & $0.001^{* *}$ \\
\hline Phen & $\begin{array}{c}026^{\mathrm{b}} \pm \\
0.11\end{array}$ & $0.29^{\mathrm{b}} \pm 0.14$ & $\begin{array}{c}2.63^{\mathrm{a}} \pm \\
1.45\end{array}$ & $\begin{array}{c}0.03^{\mathrm{b}} \pm \\
0.01\end{array}$ & UDL & UDL & $0.001^{* *}$ \\
\hline Flt & $\begin{array}{c}0.99^{\mathrm{ab}} \pm \\
0.05\end{array}$ & $1.94^{\mathrm{a}} \pm 1.35$ & UDL & UDL & UDL & UDL & $0.001^{* * *}$ \\
\hline Acy & $\begin{array}{c}1.49^{\mathrm{c}} \pm \\
0.23\end{array}$ & $4.26^{\mathrm{b}} \pm 0.17$ & $\begin{array}{c}14.33^{\mathrm{a}} \pm \\
12\end{array}$ & $\begin{array}{c}0.01^{\mathrm{c}} \pm \\
0.01\end{array}$ & $\begin{array}{c}2.49^{\mathrm{b}} \pm \\
0.97\end{array}$ & UDL & $0.007^{* *}$ \\
\hline Pyr & UDL & $0.27^{\mathrm{b}} \pm 0.11$ & UDL & $\begin{array}{c}0.03^{\mathrm{b}} \pm \\
0.02\end{array}$ & $\begin{array}{c}0.13^{\mathrm{b}} \pm \\
0.08\end{array}$ & UDL & $0.001^{* *}$ \\
\hline $\mathrm{B}(\mathrm{a}) \mathrm{A}$ & $\begin{array}{c}0.79^{\mathrm{b}} \pm \\
0.29\end{array}$ & $0.83^{\mathrm{b}} \pm 0.15$ & $\begin{array}{c}1.06^{\mathrm{a}} \pm \\
0.07\end{array}$ & $\begin{array}{c}0.02^{\mathrm{c}} \pm \\
0.01\end{array}$ & $\begin{array}{c}0.02^{\mathrm{c}} \pm \\
0.01\end{array}$ & $\begin{array}{c}0.02^{\mathrm{c}} \pm \\
0.01\end{array}$ & $0.001^{* *}$ \\
\hline $\mathrm{Chr}$ & $\begin{array}{c}0.55^{\mathrm{ab}} \pm \\
0.42\end{array}$ & $0.67^{\mathrm{a}} \pm 0.11$ & $\begin{array}{c}0.32^{\mathrm{b}} \pm \\
0.18\end{array}$ & $\begin{array}{c}0.01^{\mathrm{c}} \pm \\
0.01\end{array}$ & $\begin{array}{c}0.01^{\mathrm{c}} \pm \\
0.01\end{array}$ & $\begin{array}{c}0.01^{\mathrm{c}} \pm \\
0.01\end{array}$ & $0.001^{* *}$ \\
\hline $\mathrm{B}(\mathrm{b}) \mathrm{F}$ & $\begin{array}{c}0.89^{\mathrm{bc}} \pm \\
0.07\end{array}$ & $0.71^{c} \pm 0.09$ & $\begin{array}{c}1.03^{\mathrm{ab}} \pm \\
0.24\end{array}$ & $\begin{array}{c}0.03^{\mathrm{d}} \pm \\
0.01\end{array}$ & $\begin{array}{c}1.17^{\mathrm{a}} \pm \\
0.17\end{array}$ & $\begin{array}{c}0.03^{\mathrm{d}} \pm \\
0.01\end{array}$ & $0.001^{* *}$ \\
\hline $\mathrm{B}(\mathrm{k}) \mathrm{F}$ & $\begin{array}{c}1.53^{\mathrm{bc}} \pm \\
0.38\end{array}$ & $3.31^{\mathrm{a}} \pm 1.87$ & $\begin{array}{c}2.12^{\mathrm{ab}} \pm \\
0.76\end{array}$ & $\begin{array}{c}0.50^{\text {cd }} \pm \\
0.14\end{array}$ & $\begin{array}{c}1.03^{\text {cd }} \pm \\
0.29\end{array}$ & $\begin{array}{c}0.02^{\mathrm{d}} \pm \\
0.01\end{array}$ & $0.001^{* *}$ \\
\hline $\mathrm{B}(\mathrm{a}) \mathrm{P}$ & $\begin{array}{c}1.20^{\mathrm{a}} \pm \\
0.16\end{array}$ & $1.06^{\mathrm{b}} \pm 0.09$ & $\begin{array}{c}1.03^{\mathrm{b}} \pm \\
0.11\end{array}$ & $\begin{array}{c}0.02^{\mathrm{d}} \pm \\
0.01\end{array}$ & $\begin{array}{c}0.23^{\mathrm{c}} \pm \\
0.09\end{array}$ & $\begin{array}{c}0.02^{\mathrm{d}} \pm \\
0.01\end{array}$ & $0.001^{* *}$ \\
\hline DBA & $\begin{array}{c}0.34^{\mathrm{a}} \pm \\
0.11 \\
\end{array}$ & $0.29^{\mathrm{a}} \pm 0.19$ & $\begin{array}{c}0.28^{\mathrm{a}} \pm \\
0.10\end{array}$ & $\begin{array}{c}0.01^{\mathrm{b}} \pm \\
0.01\end{array}$ & $\begin{array}{c}0.01^{\mathrm{b}} \pm \\
0.001\end{array}$ & $\begin{array}{c}0.01^{\mathrm{b}} \pm \\
0.01\end{array}$ & $0.001^{* * *}$ \\
\hline Bghip & $\begin{array}{c}2.23^{\mathrm{a}} \pm \\
0.78\end{array}$ & $\begin{array}{c}1.64^{\mathrm{ab}} \pm \\
0.12\end{array}$ & $\begin{array}{c}2.12^{\mathrm{ab}} \pm \\
0.98\end{array}$ & $\begin{array}{c}0.02^{\mathrm{c}} \pm \\
0.01\end{array}$ & $\begin{array}{c}1.26^{\mathrm{b}} \pm \\
0.66\end{array}$ & $\begin{array}{c}0.02^{\mathrm{c}} \pm \\
0.01\end{array}$ & $0.001^{* * *}$ \\
\hline Icp & $\begin{array}{c}0.58^{\mathrm{b}} \pm \\
0.04\end{array}$ & $1.54^{\mathrm{a}} \pm 0.24$ & $\begin{array}{c}1.45^{\mathrm{a}} \pm \\
0.61\end{array}$ & $\begin{array}{c}0.02^{\mathrm{c}} \pm \\
0.01\end{array}$ & $\begin{array}{c}0.49^{b} \pm \\
0.25\end{array}$ & $\begin{array}{c}0.02^{\mathrm{c}} \pm \\
0.01\end{array}$ & $0.001^{* *}$ \\
\hline PAH4 & $\begin{array}{c}3.43 \mathrm{a} \pm \\
0.77\end{array}$ & $\begin{array}{c}3.28 \mathrm{a} \pm \\
0.27\end{array}$ & $\begin{array}{c}3.45 \mathrm{a} \pm \\
0.53\end{array}$ & $\begin{array}{c}0.09 \mathrm{c} \pm \\
0.02\end{array}$ & $\begin{array}{c}1.43 \mathrm{~b} \pm \\
0.26\end{array}$ & $\begin{array}{c}0.09 \mathrm{c} \pm \\
0.03\end{array}$ & $0.001 * *$ \\
\hline PAH8 & $\begin{array}{c}8.12 \mathrm{a} \pm \\
1.89\end{array}$ & $\begin{array}{c}10.06 \mathrm{a} \pm \\
2.49\end{array}$ & $\begin{array}{c}9.44 \mathrm{a} \pm \\
2.89\end{array}$ & $\begin{array}{c}0.65 \mathrm{c} \pm \\
0.16\end{array}$ & $\begin{array}{c}4.22 \mathrm{~b} \pm \\
1.43\end{array}$ & $\begin{array}{c}0.18 \mathrm{c} \pm \\
0.03\end{array}$ & $0.001 * *$ \\
\hline
\end{tabular}

$\mathbf{U D L}=$ Under Detection Limit. Within the same row, means with different superscripts are significantly differ $(\mathrm{P}<0.05) . *=$ Significant at $0.05(\mathrm{P}<0.05)$ 


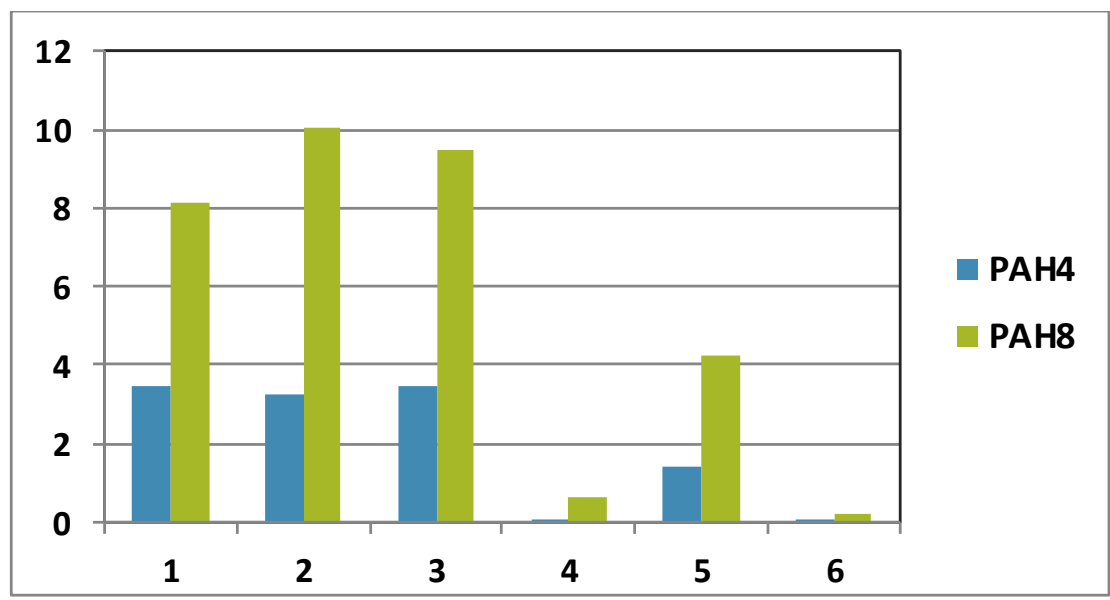

Abb.1-Charcoal grilled Kofta 2- Gas grilled Shawerma 3-Charcoal grilled Chicken 4-Gas grilled Chicken 5-Gas grilled Fish 6Smoked Herring

Fig. (1) Concentrations of PAH4 and PAH8 in the examined chicken, meat \& fish Samples exposed to different heat treatment sources.

\section{References}

Alomirah H., Al-Zenki S., AlHooti S., Zaghloul S., Sawaya W., Ahmed N. and Kannan K. (2011): Concentrations and dietary exposure to polycyclic aromatic hydrocarbons (PAHs) from grilled and smoked foods. Food Control; 22: 2028-2035.

Aygün, S. F. and Kabadayi, F., (2005): Determination of benzo[a]pyrene in charcoal grilled meat samples by HPLC with fluorescence detection. International Journal of Food Sciences and Nutrition 56(8):581-5, 2006, DOI: $10.1080 / 09637480500465$ 436.

\section{Buamden} [Association
S., (2018): between food availability and mortality due to colorectal cancer in the Americas]. Salud Colect, 14(3): 579-

595.DOI: $10.18294 / \mathrm{sc} .2018 .155$ 6 PMID: 30517564.

\section{Chung S.Y., Ramesh} R.Yettella., Kim J. S., Kwon K., Kim M. C. and David B. M,. (2011): Effects of grilling and roasting on the levels of polycyclic aromatic hydrocarbons in beef and pork. Journal of Food Chemistry; 129: 1420-1426.

DOI: 10.1016/j.foodchem.2011. 05.092 .

Darwish W.S., Chiba H., ElGhareeb , Elhelaly A.E. and Hui S.P. (2019): Determination of polycyclic aromatic hydrocarbon content in heat- 
treated meat retailed in Egypt: Health risk assessment, benzo[a]pyrene induced mutagenicity and oxidative stress in human colon ( $\mathrm{CaCo}-2)$ cells and protection using rosmarinic and ascorbic acids, Food Chemistry $290 ; 114-124$.

EC (European Commission Regulation), (2006): European Commission Regulation No. 1881/2006 amending Regulation (EC) No 466/2001 as regards polycyclic aromatic hydrocarbons. Off. J. Eur. Union L: $34 / 3$.

EC (European Commission Regulation (2011): European Commission Regulation. No $1881 / 2006$ amended by Commission Regulation (EU) No 835/2011).

EFSA (2008) European Food Safety Authority, Food Consumption, Database. http://www.efsa.europa. Eu / EFSA/ Scientific Panels/efsa locale-1178620753812.

DATEX. htm.

Eldaly E. A., Abd-Elsalam E. Hafez, Wageh S. Darwish, Rania M. Abd El-Hamid, Doaa F. Elmalt (2016): Effect of Heat Treatments on Polycyclic Aromatic Hydrocarbons Formation in Meat. Zagazig Veterinary Journal Volume 44, Number 3, p. 263-272.

EFSA (European Food Safety Authority), (2008): Scientific opinion of the panel on contaminants in the food chain on a request from the European. Commission on polycyclic aromatic hydrocarbons in food. EFSA Journal, 724, 1-114.

ES (Egyptian Standards), (2005): Detection of poisons and control. Report No.1796. Arab Republic of Egypt Egyptian. Organization for Standardization and Quality. ICS :67.120.30.

Farhadian, A., Jinap, S., Faridah, A., \&Zaidul, I. S. (2010): Determination of polycyclic

aromatic hydrocarbons in grilled meat. Food Control, 21, 606-610.

IARC (International Agency for Research on Cancer), (1987): Overall evaluation of carcinogenicity: An updating of IARC Monographs, vol. 1-42, IARC Monographs on the Evaluation of Carcinogenic Risks to Humans, Suppl. 7, International Agency for Research on Cancer, Lyon.

IARC (International Agency for Research on Cancer), (2010): Some non-heterocyclic polycyclic aromatic hydrocarbons and some related exposures. IARC Monogr Eval Carcinog Risks Hum, Vol. 92: 1-853. PMID: 21141735 PMID: 18756632.

Ikenaka, Y., Ito, Y., Eun, H., Watanabe, E. and Miyabara, Y., (2008): Characteristics of 
Accumulation Patterns of Polycyclic Aromatic Hydrocarbons in the Organisms Inhabited in Lake Suwa. J. Environmental Chemistry. Volume 18, Issue 3, Pages 341352, DOI: 10.5985/jec.18.341.

Jägerstad, M., \& Skog, K. (2005): Genotoxicity of heatprocessed foods (Review). Mutation Research, 574, 156172.

Li, G., Wu, S., Wang, L., \& Akoh, C. C. (2016): Concentration, dietary exposure and health risk estimation of polycyclic aromatic hydrocarbons (PAHs) in youtiao, a Chinese traditional fried food. Food Control, 59, 328336.

\section{Liobet, J. M., Falcó, G., Bocio,} A., and Domingo, J. L. (2006): Exposure to polycyclic aromatic hydrocarbons of edible marine species in Catalonia, Spain. Journal of Food Protection, 69, 2493-2499.

Mafiana, R.N., Al Lawati, A.S., Waly, M.I., Al Farsi, Y., Al Kindi, M., and Al Moundhri, M., (2018): Association between Dietary and Lifestyle Indices and Colorectal Cancer in Oman: A CaseControl Study. Asian Pac. J. Cancer Prev. V: 19(11), P: 3117-3122. doi: 10.31557/APJCP.2018.19.1 1.3117.PMC6318402,.
Olatunji, O. S., Fatoki, O. S., Opeolu, B. O. and Ximba, B. J. (2014): Determination of polycyclic aromatic hydrocarbons [PAHs] in processed meat products using gas Chromatography. Flame Ionization Detector. Food Chemistry 156 (2014) 296-300.

Phillips, D.H., 1999. Polycyclic Aromatic Hydrocarbons in the Diet. Mutat. Res., 443, 139147.

Reinik M., Tamme T., Roasto M., Juhkam K., Tenno T. and Kiis A. (2007): Polycyclic aromatic hydrocarbons (PAHs) in meat products and estimated PAH intake by children and the general population in Estonia. Food Additives and Contaminants, 24(4): 429-437.

Rozentale, I., Stumpe-Viksna, I., Zacs, D., Siksna, I., Melngaile, A., \& Bartkevics, $V$. (2015). Assessment of dietary exposure to polycyclic aromatic hydrocarbons from smoked meat products produced in Latvia. Food Control, 54, 16-22. 10.1016/j.foodcont.2015.01.017

Schröder Monika J. A. (2003): Food quality and consumer value, Springer, Google Books, ISBN 3-540-43914-5.

Sinha R., Peters U., Cross A. , Kulldorff M. , Weissfeld J. , Pinsky P. , Rothman N. , Hayes, R. , and Rostate Lung Colorectal and Ovarian 
Cancer Project Team (2005): contaminants? $33^{\text {rd }}$ Report of the Meat, Meat Cooking Methods Joint FAO/WHO Expert and Preservation, and Risk for Colorectal Adenoma. Cancer research, 65(17):8034-8041.

WHO (World Organization), Toxicological evaluation of certain food additives and
Committee on food additives, WHO Food Additives Series 24. Environment Health Criteria No. 202. Selected non-heterocyclic polycyclic hydrocarbons. aromatic Geneva, Switzerland.

تقييم الهيدركريونات العطرية متعددة الحلقات العبي اللحوم والأسماك المطهية بطرق حسني عبداللطيف عبدالرحمن- سلوي محمود سالم- ايناس عبدالعزير الطنطاوي

أجريت هذه الدر اسة لتقدير تركيزات الهيدروكربونات العطرية متعددة الحلقات PAH16)

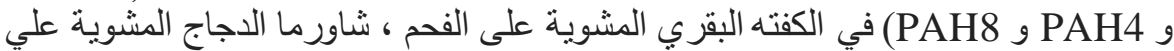

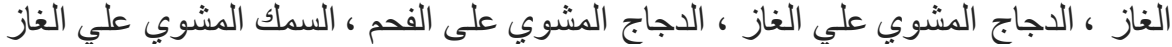

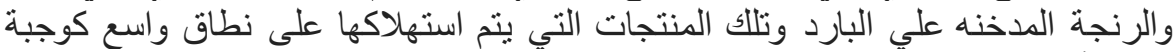

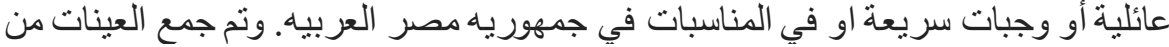

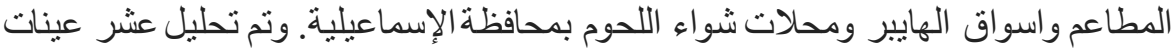

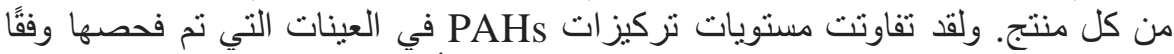

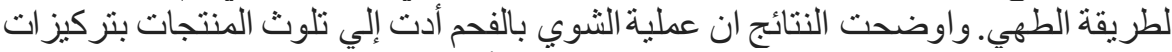

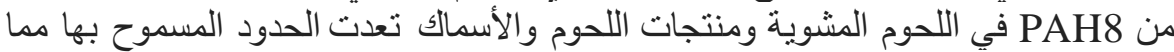
تشكل خطوره علي صحة المستهلكين. 